JIKAP PGSD: Jurnal Illmiah Illmu Kependidikan

Vol,3. No,2. Tahun 2019

e-ISSN: 2597-4440 dan p-ISSN: 2597-4424

This work is licensed under a Creative Commons Attribution

4.0 International License

\title{
Penggunaan Model Pengajaran Terarah Dalam Meningkatkan Prestasi Dan Pemahaman Pelajaran IPS Pada Siswa Kelas VIII J SMP Negeri 1 Watampone Kabupaten Bone
}

\author{
Kasma \\ Dinas Pendidikan Kabupaten Bone \\ Email: kasma@gmail.com
}

\begin{abstract}
Abstrak. Permasalahan yang ingin dikaji dalam penelitian ini adalah: (a) Bagaimanakah peningkatan prestasi belajar IPS dengan diterapkannya model pengajaran terarah (b) Bagaimana pengaruh model pengajaran terarah terhadap motivasi belajar. Tujuan dari penelitian ini adalah: (a) ingin mengetahui peningkatan prestasi belajar IPS setelah diterapkan meode belajar aktif model pengajaan terarah. (b) ingin mengetahui pengaruh motivasi belajar IPS setelah diterapkan model belajar aktif model pengajaran terarah. Penelitian ini menggunakan penelitian tindakan (action research) sebanyak tiga siklus. Setiap siklus terdiri dari empat tahap yaitu: perencanaa, pelaksanaan, pengamatan, dan refleksi. Subyek penelitian ini adalah siswa Kelas VIII J SMP Negeri 1 Watampone Kab. Bone. Data yang diperoleh berupa hasil tes formatif, lembar observasi kegiatan belajar mengajar. Pembelajaran dengan motode belajar aktif model pengajaran terarah memiliki dampak positif dalam meningkatkan prestasi belajar isiwa yang ditandai dengan peningkatkan ketuntasan belajar siswa dalam setiap siklus, yaitu siklus I (20,00\%), siklus II $(95,00 \%)$. Penerapan model belajar aktif model pengajaran terarah mampunyai pengaruh positif, yaitu dapat meningkatkan motivafi belajar siswa yang ditunjukan dengan rata-rata jawaban siswa yang menyatakan bahwa siswa tertarik dan berminat termotivasi untuk belajar.
\end{abstract}

Kata kunci: model belajar aktif model pengajaran terarah, prestasi, IPS

\begin{abstract}
The problems that need to be studied in this study are: (a) How is the improvement of social studies learning achievement by the application of directed teaching models (b) How the influence of the instructional model directed towards motivation to learn. The objectives of this study were: (a) to know the improvement in social studies learning achievements after the active learning method was applied to the directed learning model. (b) want to know the effect of social studies learning motivation after the active learning model directed learning model has been applied. This study uses action research as many as three cycles. Each cycle consists of four stages, namely: planning, implementing, observing, and reflecting. The subjects of this study were students of Class VIII J SMP Negeri 1 Watampone Kab. Bone. Data obtained in the form of formative test results, observation sheets of teaching and learning activities. Learning with active learning methods directed learning model has a positive impact in improving students' learning achievement which is characterized by increasing student mastery learning in each cycle, namely cycle I
\end{abstract}


JIKAP PGSD: Jurnal Ilmiah Ilmu Kependidikan

(20.00\%), cycle II (95.00\%). The application of the active learning model of the directed teaching model has a positive influence, which can increase the motivation of student learning as indicated by the average student response stating that students are interested and interested in being motivated to learn.

Keywords: active learning model directed teaching model, achievement, social studies

\section{PENDAHULUAN}

Pembelajaran adalah proses cara menjadikan orang atau makhluk hidup belajar. Sedangkan belajar adalah berusaha memperoleh kepandaian atau ilmu, berubah tingkah laku (positif) atau tanggapan yang disebabkan oleh pengalaman.

Dalam proses pembelajaran tidak semua anak didik mampu berkonsentrasi dalam waktu yang relatif lama. Daya serap anak didik terhadap materi yang diberikan juga bermacam-macam, ada yang cepat, ada yang sedang dan ada juga yang lambat. Faktor intelegensi mempengaruhi daya serap anak didik terhadap materi pelajaran yang diberikan. Karena itu, dalam kegiatan belajar mengajar guru harus memiliki strategi agak anak didik dapat belajar secara efektif dan efisien. Upaya untuk memiliki stragegi itu adalah guru harus menguasai model pengajaran salah satunya adalah model pengajaran terarah.

Model pengajaran terarah merupakan salingan yang mengasyikan di sela-sela cara pengajaran biasa. Cara ini memungkinkan guru untuk mengetahui apa yang guru ajarkan.

Dalam teknik ini guru mengajukan satu atau beberapa pertanyaan untuk melacak pengetahuan siswa atau mendapatkan hipotesis atau simpulan mereka dan kemudian memilahmilahnya menjadi sejumlah kategori.

Penggunaan model pengajaran terarah dalam proses belajar mengajar bukan semata persoalan mentransformasikan dan menerima materi. Akan tetapi, belajar mengajar memelurkan keterlibatn kesiapan guru dalam hal penguasaan seluruh proses pembelajaran dan kesiapan mental dan kerja siswa sendiri. Tentu hal ini akan membuahkan hasil belajar yang baik.

Untuk bisa mempelajari sesuatu dengan baik, kita perlu mendengar, melihat, mengajukan pertanyaan tentangnya, dan membahasnya dengan orang lain. Bukan cuma itu, siswa perlu mengerjakannya yakni menggambarkan sesuatu dengan cara mereka sendiri, menunjukkan contohnya, mecoba mempraktekkan keterampilan, dan mengerjakan tugas yang menuntut pengetahuan yang telah atau harus mereka dapatkan.

Setiapa akan mengajar, guru perlu membuat persiapan mengajar dalam rangka melaksanakan sebagian dari rencana bulanan dan rencana tahunan. Dalam persiapan itu sudah terkandung tentang, tujuan mengajar, pokok yang akan diajarkan, model mengejakan, materi pelajaran, alat peraga dan teknik evaluasi yang digunakan. Karena itu setiap guru harus memahami benar tentang tujuan mengajar, secara khusus memilih dan menentukan motode mengajar sesuai dengan tujuan yang hendak dicapai, cara memilih, menentukan dan menggunakan alat peraga, cara membuat tes dan menggunakannya, dan pengetahuan tentang alat-alat evaluasi.

Sementara itu teknologi pembelajran adalah salah satu dari aspek tersebut yang cenderung diabaikan oleh beberapa pelaku pendidikan, terutama bagi mereka yang menganggap bahwa sumber daya manusia pendidikan, sarana dan prasarana pendidikanlah yang terpenting. Padahal kalau dikaji lebih lanjut, setiap pembelajran pada semua tingkat pendidikan baik formal maupun non formal apalagi tingkat sekolah menegah pertama, haruslah berpusat pada kebutuhan perkembangan anak sebagai calon individu yang unik, sebagai makhluk sosial, dan sebagai calon manusia Indonesia.

Hal tersebut dapat dicapai apabila dalam aktivitas belajar mengajar, guru senantiasa memanfaatkan teknologi pembelajaran yang mengacu pada pembelajaran struktual dalam penyampaian materi dan mudah diserap peserta didik atau siswa berbeda.

Khususnya dalam pembelajaran Ilmu Pengetahuan Sosial, agar siswa dapat memahami materi yang disampaikan guru dengan baik, maka proses pembelajaran kontektual guru akan memulai membuka pelajaran dengan menyampaikan kata kunci, tujuan yang ingin 
dicapai, baru memaparkan isi dan diakhiri dengan memberikan soal-soal kepada siswa.

Dengan menyadari gejala-gejala atau kenyataan tersebut diatas, maka diadakan penelitian dengan judul"Penggunaan Model Pengajaran Terarah Dalam Meningkatkan Prestasi Dan Pemahaman Pelajaran IPS Pada Siswa Kelas VIII J SMP Negeri 1 Watampone Kab.Bone".

\section{MODEL PENELITIAN}

Penelitian ini menggunakan pendekatan kualitatif. Jenis Penelitian ini adalah penelitian tindakan( Action Research), karena penelitian dilakukan untuk memecahkan masalah pembelajaran di kelas. Penelitian ini menggambarkan bagaimana suatu teknik pembelajaran diterapkan dan bagaimana hasil yang diinginkan dapat dicapai.

Dalam penelitian ini menggunakan bentuk penelitian tindakan kolaboratif, dimana peneliti bekerja sama dengan kepala dan guru kelas. Tujuan utama penelitian tindakan kelas ialah untuk meningkatkan praktik-praktik pembelajaran di kelas. Dalam kegiatan ini, semua yang tergabung dalam penilitian ini terlibat langsung secara penuh dalam proses perencanaan, tindakan observasi, dan refleksi. Kehadiran pihak lain dalam penelitian peranannya tidak dominan dan sangat kecil.

Tempat penelitian yang digunakan dalam penelitian ini bertempat di SMP Negeri 1 Watampone Kab. Bone. Sedangkan, waktu penelitian ini dilaksanakan pada semester genap tahun pelajaran 2016/2017. Subjek Penelitian ini adalah siswa-siswa Kelas VIII J SMP Negeri 1 Watampone Kab.Bone Tahun Pelajaran 2016/2017 yang berjumlah 15 orang pada kompetensi dasar Memahami usaha persiapan kemerdekaan.

Sesuai dengan jenis penelitian yang dpilih, yaitu penelitian tindakan. maka penelitian ini menggunakan model penelitian tindakan dari kammis dan Taggart (1988: 14), yaitu berbentuk spiral dari siklus yang satu ke siklus yang berikutnya. Setiap siklus meliputi planning (rencana), action (tindakan), observation (pengamatan), dan reflection (refleksi). Sebelum masuk pada siklus 1 dilakukan tindakan pendahuluan yang berupa identifikasi permasalahan.

Penelitian ini dilaksanakan melalui 5 tahap, yaitu, (1) tahap perencanaan, (2) tahap persiapan, dan (3) tahap pelaksanaan, (4) tahap pengolahan data, dan (5) penyusunaan Laporan. Tahap-tahap tersebut dapat dirinci seperti sebagai berikut.

1. Tahap perencanaan

Pada tahap perencanaan ini kegiatan yang dilakukan meliputi, (1) observasi di sekolah, (2) penyusunan proposal penelitian.

2. Tahap Persiapan

Pada tahap persiapan ini meliputi, (1) pembuatan RP (rencana pembelajaran), (2) pembuatan LO (Lembar observasi) minat perhatian dan pastisipasi siswa, (3) pembuatan soal Tes Siklus, (4) pembuatan rambu-rambu penilaian, (5) uji coba instrument, dan (6) seleksi dan revisi instrument.

3. Tahap pelaksanaan

Tahap pelaksanaan merupakan kegiatan yang banyak berhubungan dengan lapangan dan pengolahan hasil penelitin. Tahap pelaksanaan meliputi, (1) tahap pengumpulan data dan (2) tahap pengolahan data.

4. Tahap Penyelesaikan

Pada tahap ini meliputi, (1) penyusunan laporan penelitian dan (2) penggandaan laporan.

Instrumen yang digunakan dalam penelitian ini terdari dari:

1. Rencana Pelajaran (RP)

Yaitu merupakan perangkat pembelajran yang disgunakan sebagai pedoman guru dalam mengajar dan disusun untuk tiap puturan. Masing-masing RP berisi kompetensi, dan kegiatan belajar mengajar.

2. Lembaran Kegiatan Siswa

Lembaran kegiatan ini yang dipergunakan siswa untuk membatu proses pengumpulan data hasil kegiatan pemberian tugas.

3. Tes siklus

Tes ini disususn berdasarkan tujuan pembelajran yang akan dicapai digunakan untuk mengukur kemampuan pemahaman konsep IPS pada pokok bahasan penyimpangan social. Tes siklus ini diberikan setiap akhir puturan. Bentu soal yang berikan adalah pilihan guru (objektif).

Untuk mengetahui keefektivan suatu model dalam kegiatan pembelajaran perlu diadakan analisa data. Pada penelitian ini menggunakan teknik analisis deskriftif kualitatif, yaitu suatu model penelitian yang bersifat 
menggambarkan kenyataan atau fakta sesuai dengan data diperoleh dengan tujuan untuk mengetahuai prestasi belajar yang dicapai siswa yang untuk memperoleh respon siswa terhadap kegiatan kegiatan pembelajaran serta aktivitas siswa selama proses pembelajarnan.

Untuk mengalisis tingkat kerberhasilan atau persentasi keberhasilan siswa setelah proses belajar mengaja setiap puturannya dilakukan dengan cara memberikan evalusi berupa soal tes tertulis pada setiap akhir putaran.

Analisis ini dihitung dengan menggunakan statistik sederhana:

1. Untuk menilai ulangan atau tes siklus

Peneliti melakukan penjumlahan nilai yang diperoleh siswa, yang selanjutnya dibagi dengan jumlah siswa yang ada dikelas tersebut sehingga diperoleh rata-rata tes siklus dapat dirumuskan.

$$
\begin{array}{lll}
\tilde{x}=\frac{\sum x}{\sum N} & & \\
\text { Dengan } & \tilde{x} & =\text { Nilai rata-rata } \\
& \sum x & =\text { Jumlah semua }
\end{array}
$$

nilai siswa

2. Untuk ketuntasan belajar

$$
\sum N \quad=\text { Jumlah siswa }
$$

Ada dua ketegori ketuntasan belajar yaitu secara perorangan dan secara klasial. Berdasarkan petunjuk pelaksanaan belajar mengajar kurikulum 1994 (Depdikbud, 1994), yaitu seorang siswa telah tuntas belajar bila telah mencapai skor $65 \%$ atau 75 , dan kelas disebut tuntas belajar bila di kelas tersebut terdapat $85 \%$ yang telah mencapai daya serap lebih dari atau sama dengan 65. Untuk menghitung presentase ketuntasan belajar digunakan rumus sebagai berikut: $\mathrm{P}=$ $\frac{\sum \text { siswa.yan .tuntas.belajar }}{\sum \text { siswa }} \times 100 \%$

\section{HASIL DAN PEMBAHASAN}

1. Siklus I

a. Tahap Perencanaan

Pada tahap ini peneliti mempersiapkan perangkat pembelajaran yang terdiri dari rencana pelajaran 1, LKS 1, soal Tes Siklus 1 dan alat-alat pengajaran yang mendukung.

b. Tahap Kegiatan dan Pelaksanaan

Pelaksanaan kegiatan belajar mengajar untuk siklus 1 dilaksanakan pada tanggal 1 April 2017 di Kelas VIII Jdengan jumlah siswa 30 siswa. Dalam hal ini peneliti bertindak sebagai pengamat dengan di bantu oleh teman sejawat sebagai observer. Adapun proses belajar mengajar mengacu pada rencana pelajaran yang telah dipersiapankan pengamatan (observasi) dilaksanakan bersama dengan pelaksaan belajar mengajar.

Pada akhir proses belajar mengajar siswa diberi tes siklus I degan tujuan untuk mengetahui tingkat keberhasilan siswa dalam proses belajar mengajar yang telah dilakukan. Adapun data hasil penelitian pada siklus I adalah sebagai berikut;

Tabel 4.1 Pengelolan Pembelajaran Pada Siklus I

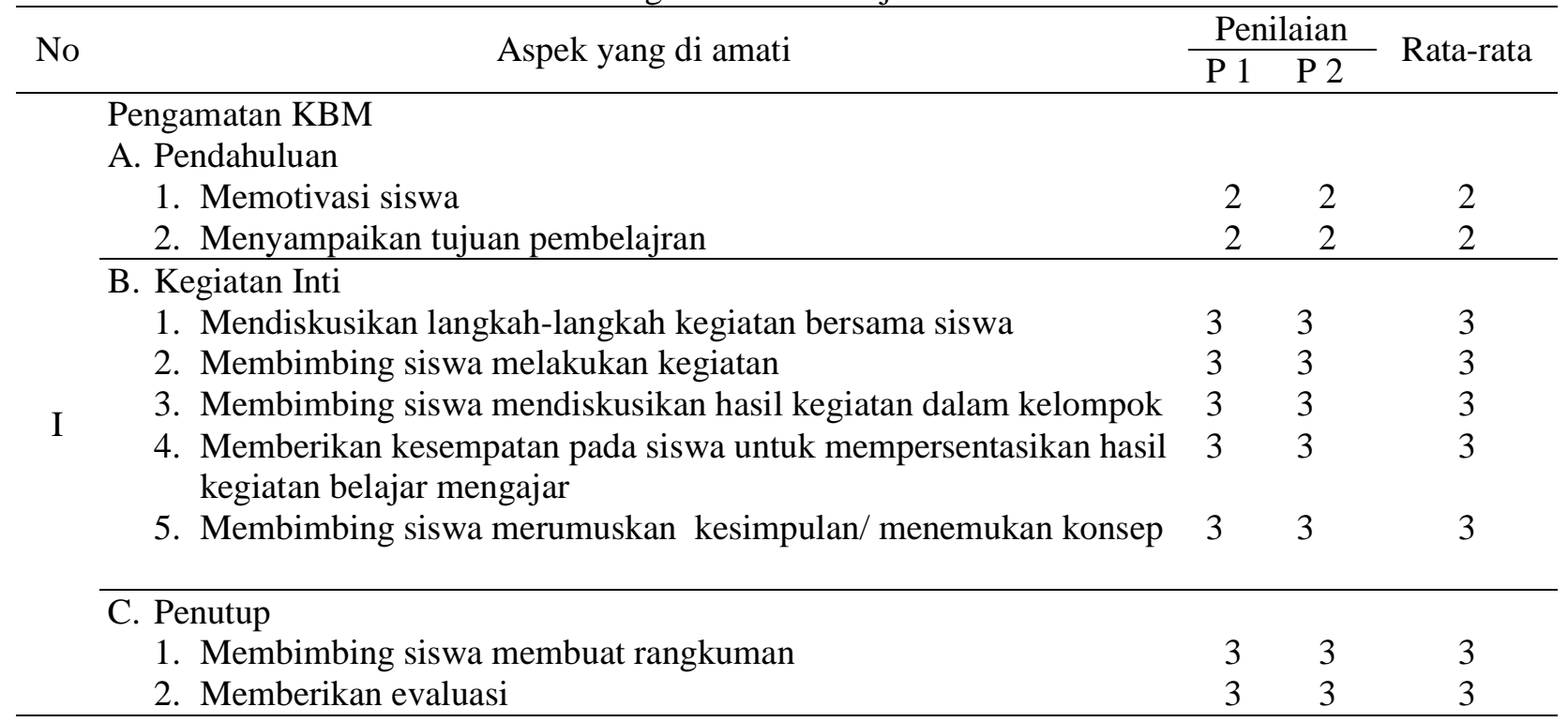




\begin{tabular}{|c|c|c|c|c|}
\hline II & Pengolalaan Waktu & 2 & 2 & 2 \\
\hline \multirow{3}{*}{ III } & Antusiasme Kelas & & & \\
\hline & 1. Siswa Antusias & 2 & 2 & 2 \\
\hline & 2. Guru Antusias & 3 & 3 & 3 \\
\hline \multicolumn{2}{|r|}{ Jumlah } & 32 & 32 & 32 \\
\hline
\end{tabular}

Keterangan: Nilai : Kriteria

1.: Tidak Baik

2.: Kurang Baik

3.: Cukup Baik

4.: Baik

Berdasarkan tabel di atas aspek-aspek yang mendapatkan kriteria kurang baik adalah memotivasi siswa, Menyampaikan tujuan pembelajaran, pengelolaan waktu, dan siswa antusis. Keempat aspek yang mendapat penilian kurang baik di atas, merupakan suatu kelemahan yang terjadi pada siklus I. Dan akan dijaikan materi kajian untuk refleksi dan revisi yang akan dilakukan pada siklus II.

Hasil observasi berikutnya adalah aktivitas guru dan siswa seperti pada tabel berikutnya.

Tabel 4.2. Aktivitas Guru Dan Siswa pada Siklus I

\begin{tabular}{llc}
\hline No & \multicolumn{1}{c}{ Aktivitas Guru yang diamati } & Presentase \\
\hline 1 & Menyampaikan tujuan & 5,0 \\
2 & Memotivasi siswa/merumuskan masalah & 8,3 \\
3 & Mengkaitkan dengan pelajaran berikutnya & 8,3 \\
4 & Menyampaikan materi/langkah-langkah/strategi & 6,7 \\
5 & Menjelaskan materi sulit & 13,3 \\
6 & Membimbing dan mengamati siswa dalam menemukan konsep & 21,7 \\
7 & Meminta siswa menyajikan dan mendiskusikan hasil kegiatan & 10,0 \\
8 & Memberikan umpan balik & 18,3 \\
9 & Membimbing siswa merangkum pelajaran & 8,3 \\
\hline No & \multicolumn{1}{c}{ Aktivitas Siswa yang diamati } & Presentase \\
\hline 1 & Mendengarkan/memperhatikan penjelasan guru & 22,5 \\
2 & Membaca buku siswa & 11,5 \\
3 & Bekerja dengan sesame anggota kelompok & 18,7 \\
4 & Diskusi antara siswa/antara siswa dengan guru & 14,4 \\
5 & Menyajikan hasil pembelajaran & 2,9 \\
6 & Mengajukan/menanggapi pertanyaan/ide & 5,2 \\
7 & Menulis yang relevan dengan KMB & 8,9 \\
8 & Merangkum pembelajaran & 6,9 \\
9 & Mengerjakan tes evaluasi & 8,9 \\
\hline
\end{tabular}

Berdasarkan tabel diatas tampak bahwa aktivitas guru yang paling dominan pada siklus I adalah membimbing dan mengamati siswa dalam menemukan konsep yaitu 21,7\%. Aktifitas lain persentasenya cukup besar adalah memberikan umpan balik/evaluasi/Tanya jawab dan menjelaskan materi yang sulit masing-masing sebesar 18,3\%dan 13,3\%. Sedangkan aktivitas siswa yang paling dominan adalah mengerjakan/memperhatikan penjelasan guru yaitu $22,5 \%$. Aktivitas lain yang persentasenya cukup besar adalah bekerja sama anggota kelompoknya, diskusi antar siswa/antara siswa dengan guru, dan membaca buku yaitu masingmasing $18,7 \%$ dan $11,5 \%$.

Pada siklus I, secara garis besar kegiatan belajar mengajar dengan merapkan model pengajaran terarah sudah dilaksanakan dengan baik, walaupun peran guru masih cukup dominan untuk memberikan penjelasan dan arahan karena model terebut masih dirasakan baru oleh siswa.

Berikutnya adalah rekapitulasi hasil tes siklus siswa seperti terlihat pada tabel berikut. 
Tabel 4.3 Rekapitulasi Hasil Tes siklus Siswa Pada Siklus I

\begin{tabular}{llc}
\hline No & \multicolumn{1}{c}{ Uraian } & Hasil Siklus I \\
\hline 1 & $\begin{array}{l}\text { Nilai rata-rata Tes Siklus } \\
\text { Jmlah siswa yang tuntas }\end{array}$ & 66,5 \\
2 & $\begin{array}{l}\text { belajar } \\
\text { Persentase } \\
\text { belajar }\end{array}$ & $34 \%$ \\
3 & kutuntasan
\end{tabular}

Dari tabel di atas dapat dijelaskan bahwa dengan menerapkan model pengajaran terarah diperoleh nilai rata-rata prestasi belajar siswa adalah 66,5 dan ketuntasan belajar mencapai 34\% atau ada 10 siswa dari 30 orang sudah tuntas belajar. Hasil tersebut menunjukkan bahwa pada siklus pertman secara klasikal siswa belum tuntas belajar, karena siswa yang memperoleh nilai $\geq 75$ hanya sebesar $34 \%$ lebih kecil dari persentase ketuntasan yang dikehendaki yaitu sebesar $85 \%$. Hal ini disebabkan karena siswa masih merasa baru dan belum mengerti apa yang dimaksudkan dan digunakan guru dengan menerapkan model pengajaran terarah.

c. Refleksi

Dalam pelaksanaan kegiatan belajar mengajar diperoleh informasi dari hasil pengamatan sebagai berikut:

1) Guru kurang baik dalam memotivasi siswa dan dalam menyampaikan tujuan pembelajaran.

2) Guru kurang baik dalam pengolalaan waktu

3) Siswa kurang begitu antusias selama pembelajaran berlanjung.

d. Refisi

Palaksanaan kegiatan belajar mengajar pada siklus I ini masih terdapat kekurangan, sehingga perlu adanya refisi untuk dilakukan pada siklus berikutnya.
1) Guru perlu lebih trampil dalam memotivasi siswa dan lebih jelas dalam menyampaikan tujuan pembelajaran. Dimana siswa diajak untuk terlibat langsung dalam setip kegiatan yang akan di lakukan.

2) Guru perlu mendistribusiakn waktu secara baik dengan menambahkan inromasiinformasi yang di rasa oerlu dan memberi catatan.

3) Guru harus lebih terampil dan bersemangat dalam memotivasi siswa sehingga siswa bias lebih anutusias.

2. Siklus II

a. Tahap perencanaan

Pada tahp ini peneli mempersikan perangkat pembelajaran yang terdiri dari rencana pelajaran 2, LKS 2, soal tes siklus 2 dan alat-alat pengajaran yang mendukung.

b. Tahap kegiatan dan pengamatan.

Pelaksanaan kegiatan belajar menjaga untuk siklus II di laksanakan pada tanggal 15April 2017 di Kelas VIII Jdengan jumlah siswa 30 siswa. Dalam hal ini peneliti bertindak sebagai pengamat dengan dibantu oleh kepala sekolah SMP Negeri 1 Watampone Kab. Bone sedangkan yang bertindak sebagai pengajar adalah. Adapun proses belajar mengajar mengacu pada rencan pelajaran dengan memperhatikan revisi pada siklus I, sehingga kesalahan atau kekurangan pada siklus 1 terulang lahi pada siklus II. Penamatan (Observasi) dilaksakan bersamaan dengan pelaksaan belajar mengajar.

Pada akhir proses belajar mengajar siswa diberi tes siklus II dengan tujuan untuk mengatahui tingkat keberhasilan siswa dalam proses belajar mengajar yang telah dilakukan. Instrumen yang digunakan adalah tes siklus II. Adapun adata hasil penelitian pada penelitian pada siklus II sebagai berikut.

Tabel 4.4 Pengelolan Pembelajaran Pada Siklus II

\begin{tabular}{|c|c|c|c|c|}
\hline \multirow[b]{2}{*}{ No } & \multirow[b]{2}{*}{ Aspek yang di amati } & \multicolumn{2}{|c|}{ Penilaian } & \multirow{2}{*}{ Rata-rata } \\
\hline & & $\mathrm{P} 1$ & $\mathrm{P} 2$ & \\
\hline \multirow{5}{*}{ I } & Pengamatan KBM & & & \\
\hline & A. Pendahuluan . & 3 & 3 & 3 \\
\hline & $\begin{array}{l}\text { 1. Memotivasi siswa } \\
\text { 2. Menyampaikan tujuan pembelajran }\end{array}$ & 4 & 4 & 4 \\
\hline & B. Kegiatan Inti & 4 & 4 & 4 \\
\hline & 1. Mendiskusikan langkah-langkah kegiatan bersama siswa & 4 & 4 & 4 \\
\hline
\end{tabular}




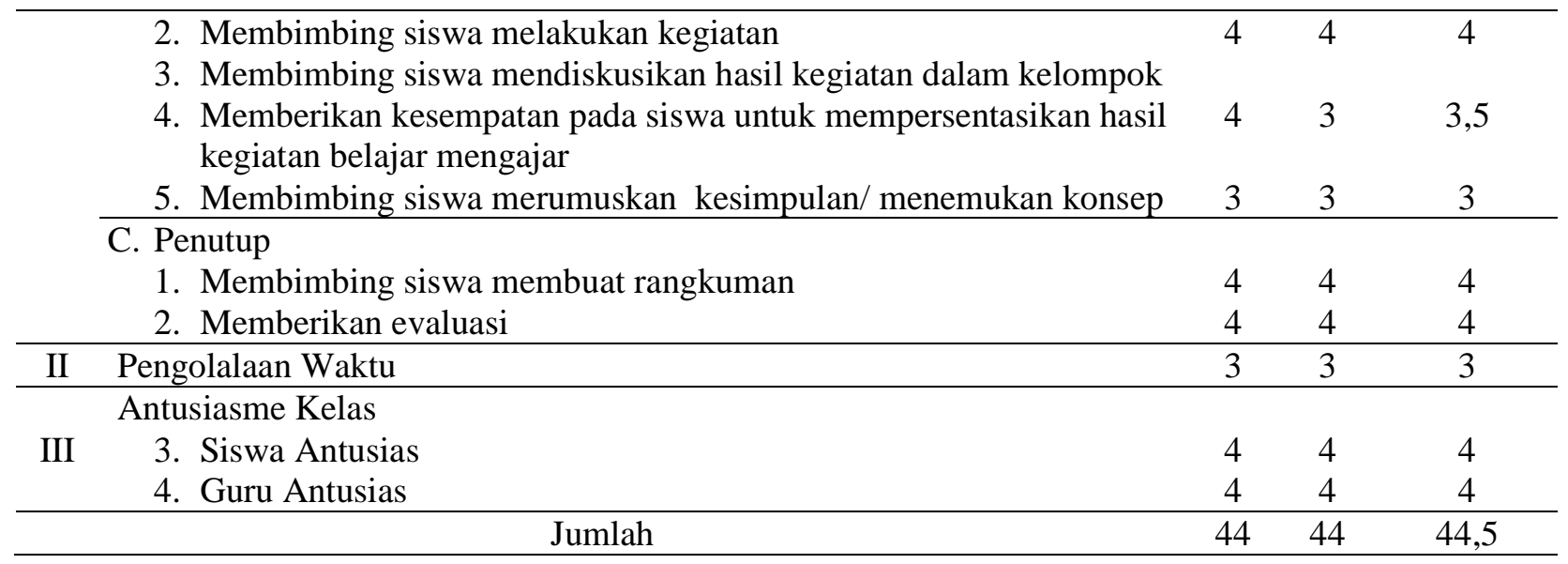

Keterangan: Nilai : Kriteria

1.: Tidak Baik

2.: Kurang Baik

3.: Cukup Baik

4.: Baik

Dari tabel di atas, dapat dilihat aspekaspek yang diamati pada kegiatan belajar mengajar (siklus II) yang dilaksanakan oleh guru dengan menerapkan model pengajaran terarah mendapatkan penilaian cukup baik dari pengamat adalah memoyivasi siswa, membimbing siswa merumuskan kesimpulan/menemukan konsep, dan pengelolaan waktu.

Penyempurnaan aspek-aspek diatas dalam menerapkan model pengajaran terarah diharapkan dapat berhasil semaksimal mungkin.

Tabel 4.2. Aktivitas Guru Dan Siswa pada Siklus I

\begin{tabular}{llc}
\hline No & \multicolumn{1}{c}{ Aktivitas Guru yang diamati } & Presentase \\
\hline 1 & Menyampaikan tujuan & 6,7 \\
2 & Memotivasi siswa/merumuskan masalah & 6,7 \\
3 & Mengkaitkan dengan pelajaran berikutnya & 10,7 \\
4 & Menyampaikan materi/langkah-langkah/strategi & 13,3 \\
5 & Menjelaskan materi sulit & 10,0 \\
6 & Membimbing dan mengamati siswa dalam menemukan konsep & 22,6 \\
7 & Meminta siswa menyajikan dan mendiskusikan hasil kegiatan & 10,0 \\
8 & Memberikan umpan balik & 11,7 \\
9 & Membimbing siswa merangkum pelajaran & 10,0 \\
\hline No & \multicolumn{1}{c}{ Aktivitas Siswa yang diamati } & Presentase \\
\hline 1 & Mendengarkan/memperhatikan penjelasan guru & 20,8 \\
2 & Membaca buku siswa & 13,1 \\
3 & Bekerja dengan sesame anggota kelompok & 22,1 \\
4 & Diskusi antara siswa/antara siswa dengan guru & 15,0 \\
5 & Menyajikan hasil pembelajaran & 2,9 \\
6 & Mengajukan/menanggapi pertanyaan/ide & 4,2 \\
7 & Menulis yang relevan dengan KMB & 6,1 \\
8 & Merangkum pembelajaran & 7,3 \\
9 & Mengerjakan tes evaluasi & 8,5 \\
\hline
\end{tabular}

Berdasarkan tabel diatas tampak bahwa aktivitas guru yang paling dominan pada siklus II adalah membimbing dan mengamati siswa dalam menemukan konsep yaitu 22,6\%. Sedangkan aktifitas menjelaskan materi yang sulit dan memberikan umpan balik/evaluasi/Tanya jawab menurun masing-masing sebesar $10 \%$ dan $11,7 \%$. Aktivitas lain yang mengalamipeningkatan adalah mengaitkan dengan pelajaran sebelumnya $10 \%$, menyampaikan materi/strategi/langkah-langkah 
$13,3 \%$ meminta siswa menyajikan dan mendiskusikan hasil kegiatan $10 \%$ dan membimbing siswa merangkum pelajaran $10 \%$. Adapunn aktivitas yang tidak mengalami perumateri adalah menyampaikan tujuan $6,7 \%$ dan memotivasi siswa $6,7 \%$. Berikutnya adalah rekapitulasi hasil tes siklus siswa seperti terlihat pada tabel berikut.

Tabel 4.6 Rekapitulasi Hasil Tes siklus Siswa Pada Siklus I

\begin{tabular}{llc}
\hline No & \multicolumn{1}{c}{ Uraian } & Hasil Siklus I \\
\hline 1 & Nilai rata-rata Tes Siklus & \\
2 & Jmlah siswa yang tuntas & 74 \\
3 & belajar & 12 \\
& $\begin{array}{l}\text { Persentase } \\
\text { belajar }\end{array}$ & kutuntasan \\
\hline
\end{tabular}

Berdasarkan tabel diatas diperoleh nilai rata-rata tes siklus sebesar 74 dan dari 30 siswa yang telah tentus sebanyak 25 siswa dan 5 siswa belum mencapai ketuntasan belajar. Maka secara klasikal ketuntasan belajar yang telah tercapai sebesar $80 \%$ (Termasuk kategori tuntas). Hasil pada siklus II ini mengalami peringkatan lebih baik dari siklus I. Adanya peningkatan hasil belajar pada siklus II ini dipengaruhi oleh adanya peningkatan kemampuan guru dalam menerapkan belajar aktif sehingga siswa menjadi lebih terbiasa dengan pembelajaran seperti ini sehingga siswa lebih mudah dalam memahami materi yang telah diberikan

c. Refleksi

Pada tahap ini akan dikaji yang telah terlaksana dengan baik maupun yang masik kurang baik dalam proses belajar mengajar dengan Penggunaan Model Pemberian Balikan. Dan data-data yang telah diperoleh dapat duraikan sebagai berikut:

1) Selama proses belajar mengajar guru telah dilakukan semua pembelajaran denagn baik. Meskipun ada beberapa aspek yang belum sempurna, tetapi presentase pelaksanaannya untk masing-masing aspek cukup besar.

2) Berdasarkan data hasil pengamatan diketahui bahwa siswa aktif selama proses belajar berlangsung.

3) Kekurangan pada siklus-siklus sebelumnya suda mengalami perbaiki dan peningkatan sehingga menjadi lebih baik.
4) Hasil belajar siswa pada siklus II mencapai ketuntasan.

d. Revisi Pelaksanaan

Pada siklus II guru telah menerapkan belajar aktif dengan baik dan dilihat dari aktivitas siswa serta hasil belajar siswa pelaksaan proses belajar mengajar sudah berjalan dengan baik. Maka tidak diperlukan revisi terlalu banyak, tetapi yang perlu diperhatikan untk tindakan selanjutnya adalah memaksimalkan dan mempertahankan apa yang telah ada dengan tujuan agar pada pelaksanan proses belajar mengajar selanjutnyapenerapan belajar aktif dapat meningkatkan proses belajar mengajar sehingga tujuan pembelajaran dapat tercapai.

1. Ketuntasan Hasil beljar Siswa

Melalui hasil penelitian ini menunujukan bahwa model pengajaran terarah memiliki dampak positif dalam meningkatkan prestasi belajar siswa. Hal ini dapat dilihat dari semakin mantapnya pemahaman siswa terhadap materi yang disampaikan guru (Ketuntasan belajar meingkat dari siklus I, dan siklus II) yaitu masing-masing $34 \%$ dan $80 \%$ siklus II ketutasan belajar siswa secara klasikal telah tercapai.

2. Kemampuan Guru dalam Mengolola Pembelajaran

Berdasarkan analisi data, diperoleh aktivitas siswa dalam proses proses belajar aktif dalam setiap siklus mengalami peningkatan. Hal ini berdampak positif terhadap prestasi belajar siswa yaitu dapat ditunjukan dengan meningkatnya nilai ratarata siswa ada setiap siklus yang terus mengalami penngkatan.

3. Aktivitas Guru dan Siswa Dalam Pembelajaran

Berdasarkan analisi data, diperoleh aktivitas siswa dalam proses pembelajaran IPS pada pokok bahasan Memahami usaha persiapan kemerdekaan dengan model pengajaran terarah yang paling dominan adalah bekerja dengan menggunakan alat/media mendengarkan/memperhatikan penjelasan guru, dan diskusi antara siswa dengan guru. Jadi dapat dikatakan bahwa aktivitas siswa dapat dikategorikan aktif. 
Sedangkan untuk aktivitas guru selama pembelajran telah melaksakan langkah-langkah belajar aktif dengan baik dengan baik. Hal ini terlihat dari aktivitas guru yang muncul di antaranya aktivitas membingbing dan mengamati siswa dalam mengerjakan kegiatan LKS/menemukan konsep,menjelaskan materi yang tidak dimengerti, memberian umpan balik/evaluasi/Tanya jawab dimana prosentase untuk aktivitas diatas cukup besar.

\section{SIMPULAN DAN SARAN}

Dari hasil kegiatan pembelajaran yang telah dilakukan selama dua siklus, dan berdasarkan seluruh pembahasan serta analisis yang telah dilakukan dapat disimpulkan sebagai berikut:

1. Pembelajaran dengan model pengajaran terarah memiliki dampak positif dalam mingkatkan prestasi belajar siswa yang ditandai dengan peningkatan ketuntasan belajar siswa dalam setiap siklus, yaitu siklus $134,00 \%$ dan siklus II $80,00 \%$.

2. Penerapan model pengajaran terarah mempunyai pengaruh positif, yaitu dapat mingkatkan motivasi belajar siswa yang ditunjukan dengan rata-rata jawaban siswa yang menyatakan bahwa siswa tertarik dan berminat dengan model pengajaran terarah sehingga mereka menjadi

Dari hasil peneitian yang diperoleh dari urutan sebelumnya agar proses belajar mengajar IPS lebih efektif dan lebih memberikan hasil yang optimal bagi siswa, maka disampaikan saran berikut:

1. Untuk melaksanakan belajar aktif memerluka persiapan yang cukup matang, sehingga guru haus mampu menentukan atau memilih topik yang benar-benar bias diterapkan dengan model Penggunaan Model Pemabrikan Balikan proses belajar mengajar sehingga diperoleh hasil yang optimal.

2. Dalam rangka meningkatkan prestasi belajar siswa, guru hendaknya lebih sering melatih siswa dengan model pembelajaran yang berbeda, walau dalam taraf yang sederhana, dimana siswa nantinya dapat menemukan pengatahuan baru, memperoleh konsep dan keterampilan, sehingga siswa berhasil atau mampu memecahkan masalah-masalah yang dihadapinya.

3. Perlu adanya penelitian yang lebih lanjut, karena hasil penelitian ini hanya dilakukan di SMP Negeri 1 Watampone Kab. Bone Tahun Pelajaran 2013/2014.

4. Untuk penelitian yang serupa hendaknya dilakukan perbaikan-perbaikan agar diperoleh hasil yang lebih baik.

\section{DAFTAR RUJUKAN}

Arikunto, Suharmi, 1993. Manajemen Mengajar Secara Manusiawi. Jakarta: Rineksa Cipta. . 2002. Dasar-Dasar Evaluasi Pendidikan. Jakarta: Bumi Aksara. .2002. Prosedur Penelitian Suatu Pendekatan Praktek. Jakarta: Bina Aksara.

Departemen Pendidikan dan Kebudayaan, 1994. Petunjuk Pelaksanaan Proses Belajar Mengajar. Jakarta. Balai Pustaka.

Djamrah. Syaiful Bahri. 2002. Strategi Belajar Mengajar. Jakarta: Rineksa Cipta.

Hadi, Sutrisno. 1981. Metodogi Research. Yayasan Penerbitan Fakultas Psikologi Universitas Gajah Mada. Yoyakarta.

Hamalik, Omer. 1994. Model Pendidikan . Bandung: Citra Aditnya Bakti..

Hasibuan. J.J. dan Moerdjiono. 1998. Proses Belajar Mengajar. Bandung: Remaja Rosdakarya.

Hudoyo, H. 1990. Strategi Belajar Mengajar Matematika. Malang: IKIP Malang.

Kemmis, S, dan Mc. Taggart, R. 1988. The Action Research Planner. Victoria Dearcin University Press.

Margono. 1997. Metodologi Penelitian Pendidikan. Jakarta. Rineksa Cipta.

Mursell, James (-). Succes Teaching (terjemahan). Pandung: Jemmars

Rustiyah, N.K. 1991. Strategi dan Motivasi Belajar Mengajar. Jakarta: Bina Aksar

Sardiman, A.M. 1996 Interaksi dan Motivasi Belajar Mengajar, Jakarta: Bina Aksara.

Soekamto, Toeti. 1997. Teori Belajar dan Model Pembelajaran. Jakarta: PAU-PPAI, Universitas Terbuka.

Usman, Moh. Uzer. 2001. Menjadi Guru Profesional. Bandung: Remaja Rosdakarya. 